\title{
Cattle Activities and Preferences Following Strip Application of Herbicide
}

\author{
R.B. SHAW AND J.D. DODD
}

\begin{abstract}
Santa Gertrudis cattle activities were dominated by grazing, standing and ruminating. Only minor differences occurred between winter and summer activities. Summer morning temperatures were negatively related to percentage of herd grazing, indicating a decrease in grazing as temperature increased. However, summer daytime vapor pressure deficit (VPD) showed a better correlation with grazing habits. As VPD increased the number of cattle grazing decreased; conversely, as VPD decreased cattle grazing increased. Cattle indicated a strong grazing preference for untreated vegetation, even though herbage production was substantially higher in the herbicide treated strips.
\end{abstract}

The Rio Grande Plain resource area of Texas is utilized almost entirely as rangeland (Thomas 1975). Much of the rangeland has become infested with woody plants and is in need of some type of brush control for range improvement (TCNC 1970). Aerial application of herbicides has become a popular and efficient means of achieving woody plant reductions. Many large pastures in the Rio Grande Plain are herbicide treated in a strip pattern. This not only controls woody plant density and stature but also provides suitable habitat for white-tailed deer (Odocoileus virginianus Boddaert) ${ }^{1}$. Knowledge of cattle activities and preferences in herbicide treated pastures is important in assisting range managers to formulate sound decisions concerning proper utilization of rangeland following treatment.

Cattle activities have been studied in the tall grass prairie by Weaver and Tomanek (1951) and Dwyer (1961). Herbel and Nelson (1966) compared Santa Gertrudis and Hereford cattle activities on the Jornada Experimental Range in New Mexico. Cory (1927) studied the habits of cattle, sheep, and goats at the Sonora Experiment Station on the Edwards Plateau of Texas. Box et al. (1965) investigated the effects of supplemental feeding on cattle activities in the Texas high plains.

Research was conducted from 1973 through 1975 in a patterned herbicide treated pasture to investigate (a) cattle activities, (b) cattle preferences for treated or untreated strips,

Authors are graduate research assistant and professor, Department of Range Science, Texas A\&M University, College Station.

This article is published with the approval of the Director, Texas Agricultural Experiment Station as TA-14379.

The authors would like to thank Mr. B.K. Johnson, owner, Chaparrosa Ranch, Zavala County, Texas, for allowing the study to be made, and the Caesar Kleberg Research Program in Wildlife Ecology at Texas A\&M University for financial support.

Manuscript received July $23,1978$.

'Scientific and common mammal names follow Davis (1974).

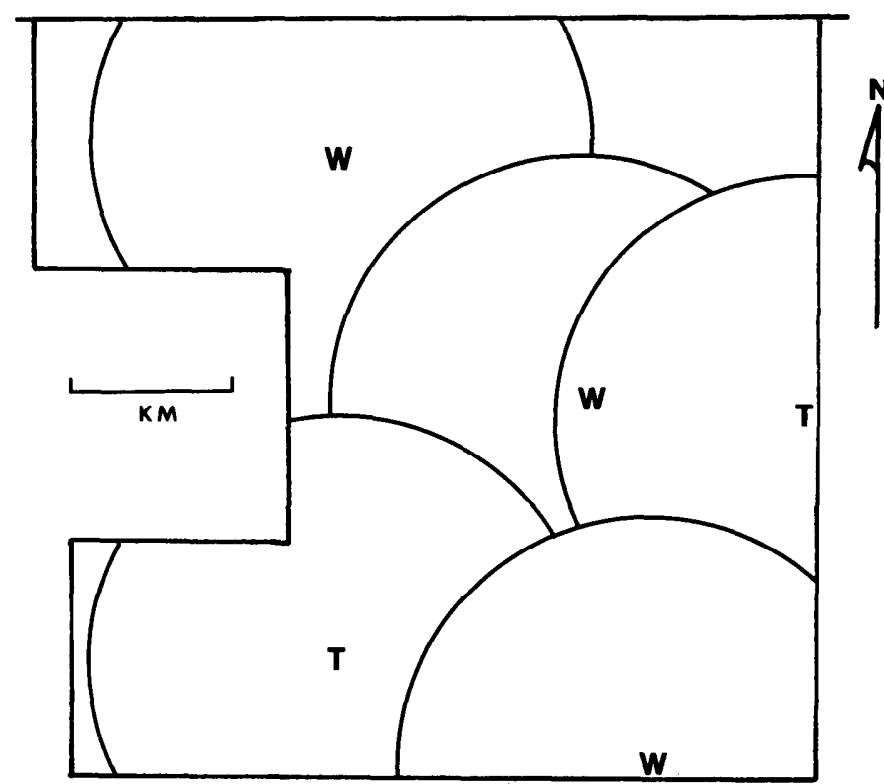

Fig. 1. Location of water stations in the Big Williams Pasture, Chaparrosa Ranch, Zavala County, Texas. Parts of the pasture not included in an arc were more than $1.6 \mathrm{~km}$ from water. Earthen tanks are indicated by $T$ and wells with concrete troughs by $W$.

and (c) relationships of grazing to selected environmental factors.

\section{Methods}

This study was conducted in the Big Williams Pasture, Chaparrosa Ranch, Zavala County, Texas. The pasture was sprayed in May 1973 with a commercial formulation of 2,4,5-T (2,4,5-trichlorophenoxy acetic acid) plus picloram (4-amino-3,5,6-trichloropicolinic acid) at a ratio of $1: 1$. The herbicide was applied on the east half of the pasture at the rate of $1.12 \mathrm{~kg} / \mathrm{ha}$ in strips averaging $476 \mathrm{~m}$ wide. The west half of the pasture received $0.56 \mathrm{~kg} / \mathrm{ha}$ in strips $1,027 \mathrm{~m}$ wide. Untreated strips on the east and west sides of the pasture averaged $165 \mathrm{~m}$ and 252 $\mathrm{m}$ wide, respectively. Approximately $80 \%$ of the pasture was treated. Treatment effects on woody and herbaceous plants have been reported by Shaw (1976). Impact of the strip treatment on deer habitat has been reported by Tanner et al. (1978).

A continuous grazing system was utilized in the pasture during the study with occasional deferments ranging from $45-60$ days $^{2}$. The

2 Personal communications with Wayne Hamilton, former resource manager, Chaparrosa Ranch, and currently, instructor, Department of Range Science, Texas A\&M University, College Station. 
stocking density in October 1973 was 181 animal units (AU) of Santa Gertrudis on the 1,860-ha pasture. The density was increased to 263 AU in April 1975. These densities do not include 12-16 bulls that were placed in the pasture for about 6 months each year. All areas of the pasture were less than $1.6 \mathrm{~km}$ from water except for small areas in the northwest, northeast, and southwest corners (Fig. 1). Salt and liquid supplement were located near the watering stations.

Cattle activities were determined by herd observations made at 5-minute intervals (Peterson and Woolfolk 1955; Hull, et al. 1960). Observations were made during the summer and winter 1974 and summer 1975. Daytime observations began at dawn and lasted until dark, while nighttime observation periods started at dusk and continued to dawn. A total of 21 summer daytime observation periods were made, while summer nighttime activities were based on 10 observation periods. Winter daytime activities were determined from 11 observation periods. No winter nighttime observations were conducted. A group of cattle was located and followed during the entire observation period. Activities recorded were browsing, defecating, grazing, lying, ruminating, standing, supplementing, urinating, walking, and watering (Dwyer 1961). Observations were made from existing windmills, hunting stands, and a truck-mounted tower. Time of day, number of animals per activity, and location in treated and untreated strips were recorded with each observation.

Ambient temperature and relative humidity were measured each hour with a sling psychrometer (Ehrenreich and Bjugstad 1966). Relative humidity data were converted to vapor pressure deficit (VPD). Cloud cover, wind direction, and wind velocity were recorded each hour. Cattle movements during an observation period were mapped and measurements were made to determine total distance traveled.

Grazing preference for treated or untreated strips was estimated by observation and comparison of herbage production in exclosure cages to production outside cages. Forty-five wire exclosures $(5 \mathrm{~m}$ by $5 \mathrm{~m}$ ) were located in two treated and two untreated strips. Two $0.5-\mathrm{m}^{2}$ quadrats were harvested both inside and outside the exclosures in November 1973, June 1974, October 1974, June 1975, and October 1975. Herbage was clipped to approximately $5 \mathrm{~cm}$ above ground level, oven dried at $100^{\circ} \mathrm{C}$, and weighed. Grasses and forbs were segregated.

\section{Results}

\section{Summer Cattle Activities}

The average summer daylight period was approximately 16 hours $(\mathrm{h})$. Cattle generally rose before daylight $(0500)$ and started grazing while calves nursed. After 3 to $5 \mathrm{~h}$ of intense grazing the herd would move toward water, but not always the nearest water. Cattle close to water grazed to within a few hundred meters and then walked directly to the station. Those at greater distances began to graze in the general direction of water but would stop, sometimes $1 \mathrm{~km}$ or more from water, and walk to the station without hesitation.

Herds generally arrived at a water station between 0900-1100 and drank immediately. At large earthen tanks cattle spaced themselves and all drank at the same time. At troughs they often disturbed each other while drinking and some animals were forced to wait.

After watering, most cows initiated a lengthy midday rest period, lasting about $5 \mathrm{~h}$. During this period they would alternately rest (standing or lying) and ruminate. Approximately $20 \%$ of the cows grazed during this midday rest period. In addition, they watered and salted intermittently and calves nursed once or twice.

Cows generally would leave water stations in the afternoon (1600-1800) in the same pattern utilized in movement to the stations. Some herds moved several hundred meters from the station and began to graze, while others moved up to $1 \mathrm{~km}$ before initiating the evening grazing period.

Evening grazing lasted from about $1700-2100$, and calves nursed during the early part of the period. By dusk (2100), cows were generally at a bedding area and began to lie and ruminate. Movement after dark was minimal and walking was only associated with grazing. Nighttime cattle activities were mainly ruminating, resting, and grazing. The high percentage of cattle grazing at night was primarily due to continuation of grazing after sundown or grazing initiated prior to dawn; however, some cows did graze during the night between 2400-0200.

Major activities (grazing, standing, ruminating, walking, and lying) accounted for $89.5 \%$ of summer daytime activities (Table 1). Of these five major activities, grazing and standing were most important. Ruminating and walking were nearly equal with 17.5 and $15 \%$, respectively. Minor activities accounted for the remaining $10.5 \%$ of the day.

Ruminating and lying accounted for over $67 \%$ of the nighttime activities, while grazing accounted for $24 \%$ (Table 1 ). In contrast to daytime activities, standing and walking were of limited importance. No browsing, watering, or supplementing were observed to occur at night.

\section{Winter Cattle Activities}

Average hourly winter activities were similar to those of

Table 1. Percentage time spent during summer day, summer night, and winter day by cattle at specified activities and h/activity. Data based on observations made during summer and winter 1974 and summer 1975. Summer data are means of 1974 and 1975 observations.

\begin{tabular}{|c|c|c|c|c|c|c|}
\hline \multirow[b]{2}{*}{ Activity } & \multicolumn{4}{|c|}{ Summer } & \multicolumn{2}{|c|}{ Winter } \\
\hline & $\begin{array}{c}\text { Daytime } \\
(\%)\end{array}$ & h/Activity & $\begin{array}{l}\text { Nighttime } \\
(\%)\end{array}$ & h/Activity & $\begin{array}{l}\text { Daytime } \\
(\%)\end{array}$ & h/Activity \\
\hline \multicolumn{7}{|l|}{ Major } \\
\hline Grazing & 26.0 & 4.16 & 24.0 & 1.92 & 24.0 & 3.12 \\
\hline Standing & 22.0 & 3.51 & 3.0 & 0.24 & 20.0 & 2.60 \\
\hline Ruminating & 17.5 & 2.80 & 36.0 & 2.88 & 18.0 & 2.34 \\
\hline Walking & 15.0 & 2.40 & 4.0 & 0.32 & 15.0 & 1.95 \\
\hline Lying & 9.0 & 1.44 & 31.6 & 2.53 & 11.0 & 1.43 \\
\hline Total & 89.5 & 14.31 & 98.6 & 7.89 & 88.0 & 11.44 \\
\hline \multicolumn{7}{|l|}{ Minor } \\
\hline Nursing & 4.0 & 0.64 & 1.1 & 0.08 & 1.4 & 0.18 \\
\hline Watering & 3.0 & 0.48 & 0 & 0 & 2.0 & 0.26 \\
\hline Browsing & 2.0 & 0.32 & 0 & 0 & 5.0 & 0.65 \\
\hline Supplementing & 0.6 & 0.10 & 0 & 0 & 3.0 & 0.39 \\
\hline Defecating & 0.6 & 0.10 & 0.1 & 0.01 & 0.3 & 0.04 \\
\hline Urinating & 0.3 & 0.05 & 0.2 & 0.02 & 0.3 & 0.04 \\
\hline Total & 10.5 & 1.69 & 1.4 & 0.11 & 12.0 & 1.56 \\
\hline
\end{tabular}


summer. However, the average daylight period was approximately 3 to $4 \mathrm{~h}$ shorter $(12-13 \mathrm{~h})$. The morning grazing period started about 1 to $2(0600-1100)$ h later than in summer and lasted about $1 \mathrm{~h}$ longer. The midday rest period was from about 1100-1500, approximately $2 \mathrm{~h}$ shorter than in summer. Evening grazing was initiated at 1500 and lasted to about 1800 .

The five major activities (grazing, standing, ruminating, walking, and lying) accounted for $88 \%$ of the winter daytime activities (Table 1). Grazing and standing dominated, while ruminating and walking were nearly equal in importance. Browsing and supplementing were the most important minor activities.

\section{Cattle Movements}

Cattle movements in the study area appeared related to spacing of water stations and preferred bedding areas. Estimated average distances traveled daily by cattle during
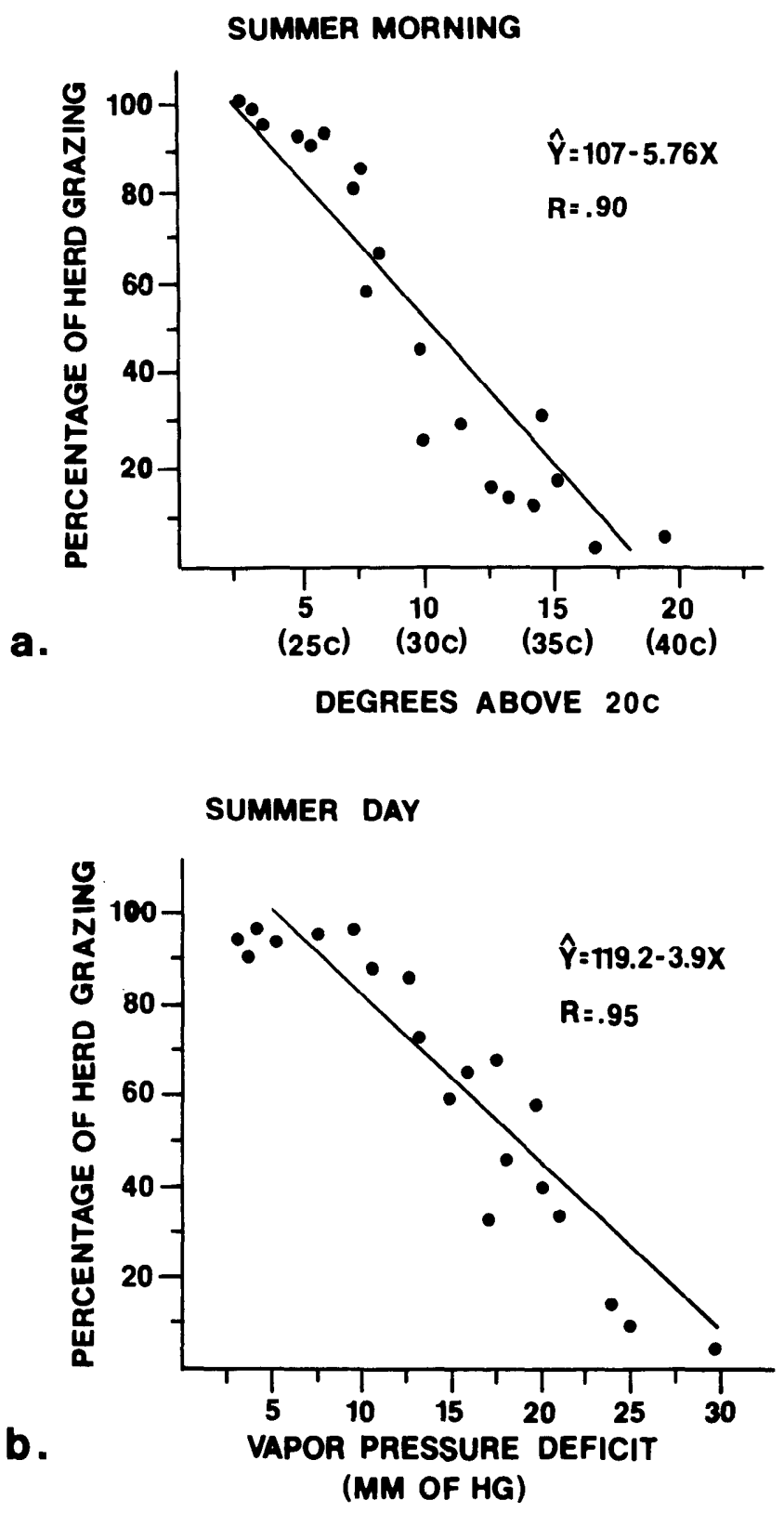

Fig. 2. Regression of percentage of herd grazing to (a) temperatures during summer morning and to (b) vapor pressure deficit (VPD) for total summer day. summer and winter were 5.8 and $4.7 \mathrm{~kg} /$ day, respectively. Maximum daily distance traveled was estimated to be $11.1 \mathrm{~km}$ (summer), while the minimum distance was $2.4 \mathrm{~km}$ (winter). Most cattle movements occurred during the morning and evening periods when the animals were grazing to and from water. Average distance traveled during the midday rest period for both seasons was estimated at $1 \mathrm{~km}$.

\section{Effect of Temperature and VPD on Grazing}

Summer daytime (0600-2000) temperatures and grazing habits of cattle were not significantly correlated $\left(r^{2}=0.22\right)$ $(P>0.05)$. However, the coefficient of determination for summer morning $(0600-1200)$ temperatures and percent of herd grazing was $r^{2}=0.90(P<0.05)$ (Fig. 2). The regression equation $Y=107.0-5.76 \mathrm{X}$ indicated that each unit increase in temperature above $20^{\circ} \mathrm{C}$ resulted in a $5.76 \%$ decrease in cattle grazing. Summer temperatures did not correlate with grazing during the afternoon and evening $(1300-2000)\left(r^{2}=0.08\right)$ $(P>0.05)$.

Summer daytime VPD was correlated $\left(r^{2}=0.92\right)(P<0.05)$ with percent of herd grazing (Fig. 2). 'The regression equation $Y$ $=119.2-3.9 \mathrm{X}$ indicated that each unit increase in VPD resulted in a decrease of $3.9 \%$ in cattle grazing.

Temperatures and VPD were not significantly correlated with the percentage of cattle grazing during winter. Correlation of determination for temperature and VPD were $r^{2}=0.05$ and $r^{2}=$ 0.03 , respectively $(P \leq 0.5)$.

\section{Cattle Preference}

The difference in grass standing crop inside and outside grazing exclosures indicated that cattle utilized more forage in the untreated strips than in the treated areas (Fig. 3). The

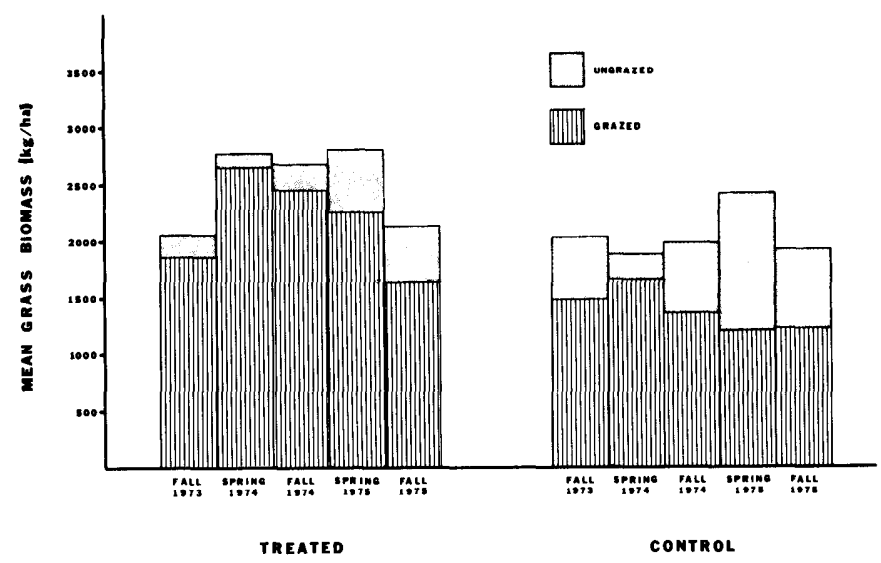

Fig. 3. Grass biomass (kg/ha oven dried) inside and outside grazing exclosures at five harvest dates in treated and control (untreated) strips in the Big Williams Pasture, Chaparrosa Ranch, Zavala County, Texas.

untreated vegetation accounted for approximately $20 \%$ of the pasture ( $470 \mathrm{ha}$ ). Grass biomass was greater on the treated strips than on the untreated strips at all harvest dates. The least difference in utilization between treatments was in spring 1974, while the greatest difference was in spring 1975. Total utilization in the pasture for 1974 and 1975 was about 17 and $33 \%$, respectively. The increased utilization in 1975 reflected an increase in stocking density from $181 \mathrm{AU}$ to $263 \mathrm{AU}$ in 1975.

Observation data also reflected a grazing preference for untreated strips. Chi-square analysis of observed grazing behavior indicated that significantly more grazing $(P<0.05)$ occurred in untreated strips both in the morning and evening grazing period. The midday period was dominated by activities 
centered around water stations that were all located in treated strips. Consequently, during the midday period, cattle showed a significant preference for these strips $(P<0.05)$.

Observations indicated that cattle browsed twisted acacia (Acacia tortuosa (L.) Willd.) ${ }^{3}$, prickly pear (Opuntia spp.), and honey mesquite (Prosopis glandulosa Torr. var. glandulosa). Pricklypear was used throughout the year, but was utilized about twice as much in winter as summer. Mesquite was browsed most heavily when producing fruit. The pods were consumed either from the tree or from the ground. Mesquite pod material and germinating seeds were evident in fecal matter. Twisted acacia was browsed in early spring during growth initiation and flowering.

\section{Discussion}

Cattle activities were dominated by grazing, standing, walking, lying, and ruminating. These five major categories accounted for about $90 \%$ of summer and winter daytime activities. Similar results were reported by Herbel and Nelson (1966). Little variation between cattle activities in winter and summer was noted except in minor categories. For example, in summer cattle spent about twice as much time watering. They browsed approximately twice as much and took supplement about four times as much winter as in summer. This could account for the $2 \%$ reduction in grazing during the winter.

About $26 \%$ of summer daytime activities were spent grazing. In contrast, Cory (1927), Dwyer (1961), and Herbel and Nelson (1966) reported 56, 40, and $38 \%$, respectively. This difference may be related to differences in forage production at the various study sites or in the definition of grazing. In this study, cattle were considered to be grazing when actively engaged in consuming forage. However, in other studies grazing-walking was considered as part of the grazing activity.

Santa Gertrudis cattle in this study walked approximately 6 and $5 \mathrm{~km} /$ day in summer and winter, respectively. These distances were similar to those reported by Cory (1927), Dwyer (1961), and Box et al. (1965). In contrast, Herbel and Nelson (1966) reported travel of about 16 and $15 \mathrm{~km} /$ day in summer and winter, respectively, for Santa Gertrudis. This also may reflect differences in forage availability, topography and water spacing among the different study sites.

Vapor pressure deficit was significantly correlated with grazing habits during summer daytime. Only summer morning temperatures were significantly correlated with grazing. The low correlation of afternoon and evening temperatures to grazing could be related to the high afternoon and evening temperatures (average $37^{\circ} \mathrm{C}$ ) of south Texas. Regardless of

\footnotetext{
3 Scientific and common plant names follow Gould (1975)
}

temperature, cattle occasionally grazed during the midday rest period and commenced grazing in the afternoon. Thus, hunger probably was the influencing factor on afternoon grazing rather than temperature. Dwyer (1961) reported a high correlation between grazing and summer daylight temperatures. No correlation between temperatures and VPD and cattle grazing was indicated for winter. This reflects the wide temperature fluctuations (very cold to very warm) recorded during the winter months.

Based on qualitative observations, Fisher, et al. (1959) reported that cattle showed a grazing preference for herbicide treated areas. However, clipping data from this study indicated that cattle utilized more grass in untreated vegetation strips than in treated strips at all seasons. Evaluation of behavior data also suggests the same preference.

\section{Literature Cited}

Box, T.W., G. Brown, and J. Liles. 1965. Influence of winter supplemental feeding of cottonseed cake on activities of beef cows. J. Range Manage. 18:124-126.

Cory, V.L. 1927. Activities of livestock on the range. Texas Agr. Coll. Exp. Bull. 357.47 p.

Davis, W.B. 1974. The mammals of Texas. Texas Parks and Wildlife Bull. No. 41. $294 \mathrm{p}$.

Dwyer, D.D. 1961. Activities and grazing preference of cows with calves in Northern Osage County, Oklahoma. Okla. Agr. Exp. Sta. Bull. B-588.61 p.

Ehrenreich, J.H., and A.J. Bjugstad. 1966. Cattle grazing time is related to temperature and humdity. J. Range Manage. 19:141-142.

Fisher, C.E., C.H. Meadows, E.D. Robinson, P.T. Marion, and H.L. Morton. 1959. Control of mesquite on grazing lands. Texas Agr. Exp. Sta. Bull. 935. 24 p.

Gould, F.W. 1975. Texas Plants: a checklist and ecological summary. Texas Agr. Exp. Sta. MP-585/Revised. 112 p.

Herbel, C.H., and A.B. Nelson. 1966. Activities of Hereford and Santa Gertrudis cattle on a Southern New Mexico Range. J. Range Manage 19:173-176.

Hull, J.L., G.P. Lofgreen, and J.H. Meyer. 1960. Continuous versus intermittent observations in behavior studies with grazing animals. J. Animal Sci. 19:1204-1207.

Peterson, R.A., and E.J. Woolfolk. 1955. Behavior of Hereford cows and calves on short grass range. J. Range Manage. 8:51-57.

Shaw, R.B. 1976. Vegetation response and cattle activities following patterned herbicide application. MS Thesis. Texas A\&M Univ., College Station. 102 p.

Tanner, G.W., J.M. Inglis, and L.H. Blankenship. 1978. Acute impact of herbicide strip treatment on mixed-brush white-tailed deer habitat on northern Rio Grande Plain. J. Range Manage. 31:386-391.

Texas Conservation Needs Committee. 1970. Conservation needs inventory. Soil Conservation Service, Temple, Texas. 297 p.

Thomas, G.W. 1975. Texas plants: an ecological summary, p. 7-14. In: F.W Gould, Texas Plants: a Checklist and Ecological Summary. Texas Agr. Exp. Sta. MP-585/Revised. 112 p.

Weaver, J.E., and G.W. Tomanek. 1951. Ecological studies in a midwestern range: The vegetation and effects of cattle on its composition and distribution. Univ. Nebraska Conserv. Bull. No. 31.82 p. 